\title{
ROKOK ELEKTRIK (VAPE) SEBAGAI GAYA HIDUP PEROKOK MASA KINI DI KOTA LHOKSEUMAWE
}

\author{
Doli Satria Maulana Hutapea, Teuku Kemal Fasya *) \\ ${ }^{*}$ Program Studi Antropologi Universitas Malikussaleh, kemal_antropologi2@yahoo.co.uk
}

\begin{abstract}
In all parts of the world, every human being has various kinds of habits. One of the human habits is smoking. Today, smoking itself is not something that is considered taboo by society. Cigarettes have become objects that are familiar to humans in general. This smoking habit is difficult to break. On this occasion, researchers will try to raise a theme of smoking habits that have become more modern among teenagers, namely vape as a lifestyle for today's smokers. The background of this research is the author's curiosity about why active smokers, especially teenagers, consume vapes as a substitute for tobacco cigarettes. As for the problem formulation in this study, namely why has vape become a trend in Lhokseumawe City? What effect does vape have on the lifestyle of today's smokers? This research took place in Lhokseumawe City. The method used in this research is qualitative research with data collection techniques, namely observation, interviews, documentation, and literature studies using the perspective of consumerism culture and lifestyle studies.
\end{abstract}

ABSTRACT

Keywords: Vape, Lifestyle, Consumerism

\begin{abstract}
ABSTRAK
Setiap manusia di seluruh belahan dunia memiliki berbagai macam kebiasaan. Salah satu kebiasaan itu adalah merokok. Dewasa ini, merokok bukanlah hal yang dianggap tabu oleh masyarakat. Rokok sudah menjadi benda yang sudah tidak asing lagi bagi manusia pada umumnya. Pada kenyataannya kebiasaan merokok ini sulit dihilangkan. Pada kesempatan ini, peneliti akan coba mengangkat sebuah tema kebiasaan merokok yang kini telah menjadi lebih modern di kalangan remaja, yaitu rokok elektrik (vape) sebagai gaya hidup perokok masa kini. Yang melatarbelakangi penelitian ini adalah keingintahuan penulis mengapa kini perokok aktif khususnya para remaja mengonsumsi vape sebagai pengganti rokok tembakau. Adapun yang menjadi rumusan masalah dalam penelitian ini yaitu mengapa rokok elektrik menjadi tren di Kota Lhokseumawe? Apa pengaruh rokok elektrik bagi gaya hidup perokok masa kini? Penelitian ini bertempat di Kota Lhokseumawe. Metode yang digunakan dalam penelitian ini adalah penelitian kualitatif dengan teknik pengambilan data yaitu observasi, wawancara, dokumentasi, dan studi literatur dengan menggunakan perspektif kajian budaya konsumerisme dan gaya hidup.
\end{abstract}

Kata Kunci: Rokok Elektrik, Gaya Hidup, Konsumerisme. 


\section{PENDAHULUAN}

Dewasa ini merokok bukanlah hal yang dianggap tabu. Rokok merupakan benda yang sudah tidak asing lagi bagi manusia pada umumnya. Merokok sudah menjadi kebiasaan yang sangat umum dan meluas di tengah masyarakat. Pada kenyataannya kebiasaan merokok sudah sulit dihilangkan dan jarang diakui orang sebagai suatu kebiasaan buruk. Menurut WHO, Indonesia menduduki peringkat ketiga sebagai jumlah perokok terbesar di dunia (Fikriyah \& Febrijanto, 2012: 100), dan kini Indonesia juga mencetak rekor baru, yakni jumlah perokok remaja tertinggi di dunia. Tercatat sebanyak 19,2\% pelajar saat ini menghisap rokok (Global Youth Tobacco Survey, 2019).

Rokok adalah lintingan tembakau yang digulung/dibungkus dengan kertas, daun, atau kulit jagung, sebesar kelingking dengan panjang 8-10 cm, biasanya dihisap seseorang setelah dibakar ujungnya. Sunaryo dalam Fikriyah \& Febrijanto (2012: 100) mengatakan bahwa merokok adalah perilaku yang berbahaya bagi kesehatan, tetapi masih banyak orang yang melakukannya, bahkan orang mulai merokok ketika masih remaja. Padahal hanya dengan membakar dan menghisap sebatang rokok saja, dapat diproduksi lebih dari 4.000 jenis bahan kimia. Sekitar 400 diantaranya beracun dan 40 diantaranya bisa berakumulasi dalam tubuh dan dapat menyebabkan kanker. Rokok juga termasuk zat adiktif karena dapat menyebabkan adiksi (ketagihan) dan dependensi (ketergantungan) bagi orang yang menghisapnya. Dengan kata lain, rokok termasuk golongan narkotika, psikotropika, alkohol, dan zat adiktif (BPOM RI, 2015).

Di Indonesia kini muncul suatu trend baru yaitu penggunaan rokok elektrik. Rokok elektrik digunakan untuk mengurangi rasa kecanduan terhadap rokok tembakau bagi perokok aktif. Rokok elektrik sudah lama diciptakan, namun baru dipatenkan pada beberapa tahun belakangan ini seluruh negara termasuk Indonesia. Karena melepas rokok bukan hal yang mudah, sehingga inilah awal kemunculan personal vaporizer. Menggunakan personal vaporizer adalah cara alternatif untuk berhenti merokok. Oleh karena itu, vaping menjadi salah satu pilihan gaya hidup yang lumayan sehat daripada merokok. Vaping juga bisa membuat candu, karena efek nikmatnya melihat uap yang dikeluarkan begitu banyak.

Semakin meningkatnya penggunaan rokok elektrik berarti semakin berubahnya gaya hidup seseorang. Vaping atau "nge-vape" merupakan salah satu cara terbaik untuk berhenti merokok menurut sebagian besar dokter. Vaporizer memang sedang menjadi gaya hidup kekinian di kalangan masyarakat, bahkan hampir setiap kota di Indonesia memiliki toko dan komunitas vaporizer sebagai tempat bersosialisasi. Tujuan dibentuknya komunitas tersebut untuk belajar 
membuat coil baru, memasukkan kapas, dan melakukan firing liquid. Selain itu, merawat mod, atomizer, dan membuat eliquid sendiri.

Di kota Lhokseumawe terdapat tiga toko rokok elektrik yang menjual segala jenis kebutuhan bagi pengguna rokok elektrik. Dari masing-masing toko rokok elektrik tersebut terdapat juga komunitas vaporizer-nya. Belum bisa dipastikan berapa jumlah konsumen rokok elektrik di Kota Lhokseumawe, namun berdasarkan informasi dari para pemilik toko, pelanggan mereka setiap tahun terus mengalami peningkatan. Peneliti melihat hal ini dikarenakan komunitas yang mereka bentuk bukanlah komunitas resmi, melainkan dibentuk begitu saja oleh karena mereka sering berkumpul di salah satu toko rokok elektrik yang mereka kunjungi. Melihat pada perkembangan itu, peneliti sangat tertarik untuk meneliti mengenai trend rokok elektrik di Kota Lhokseumawe karena kota ini sudah banyak remaja dan orang dewasanya yang menjadi pelanggan toko rokok elektrik.

Penelitian terdahulu yang terkait dengan tema gaya hidup dilakukan oleh Marisa (2017). Studi ini memfokuskan pada budaya mimikri para fashionista yang senantiasa memiliki animo terhadap trend fashion. Adapun studi yang terkait dengan tema rokok elektrik pernah dilakukan oleh Atmojo (2017) yang berfokus pada aspek psikologis konsumen yang beralih dari perokok tembakau menjadi perokok elektrik. Sementara studi yang peneliti lakukan ini berfokus pada kajian budaya konsumerisme rokok elektrik.

\section{Konsep Gaya Hidup dan Budaya Konsumerisme}

Budaya menurut Keesing (1981) lebih diartikan sebagai himpunan pengalaman yang dipelajari. Dalam Antropologi, meneliti dan menganalisa berbagai cara hidup manusia dan berbagai sistem tindakan manusia, aspek belajar merupakan hal yang pokok (Koentjaraningrat, 2009). Budaya populer adalah seni mengolah apa yang dihasilkan oleh sistem. Kreativitas budaya pop tidak semata-mata terletak pada produksi komunitas-komunitas industrial. Seni masyarakat adalah seni "mengolah" (Certau dalam Fiske, 2011). Agar menjadi budaya pop ia harus diterima oleh "rakyat"; ia harus memprovokasi percakapan dan memasuki sirkulasi dan resirkulasi oral. Pada akhirnya seperti hal-hal lain yang disediakan oleh media dan industri budaya, ia harus dibuat populer (Storey, 2008). Dalam studi ini peneliti menggunakan gagasan pop culture untuk mengkaji bagaimana komunitas vaporizer mengonsumsi produk tersebut.

Konsumsi bisa ditemukan dalam pelbagai studi mengenai budaya penggemar (fan culture) dan budaya belanja sebagai bentuk budaya pop. Sebagai ideologi, konsumerisme mendorong kebutuhan palsu dan bahwa kebutuhan ini bekerja sebagai satu bentuk kontrol sosial (Storey, 2010; 
Bakti et al., 2019). Ideologi ini menjelaskan bagaimana keinginan seseorang untuk menjadi jenis orang tertentu, mengenakan tipe pakaian tertentu, memakan macam makanan tertentu, meminum minuman khusus, dan menggunakan barang-barang khusus seperti rokok elektrik.

Menurut Featherstone dalam Alfitri (2017), ada tiga perspektif utama budaya konsumen, yaitu: 1) ekspansi produksi komoditas kapitalis, 2) kepuasan terhadap benda-benda yang berhubungan dengan status sosial, dan 3) masalah kesenangan emosional untuk konsumsi. Menurut Walker (2010) ada beraneka ragam tipe dan fase kesenangan dan sangat erat hubungannya dengan konsumerisme, diantaranya: 1) kesenangan hasrat, 2) kesenangan membeli, 3) kesenangan atas objek itu sendiri, 4) kesenangan guna, dan 5) kesenangan berkenaan dengan yang lain yaitu kesan yang dibuat seseorang melalui kepemilikan barang-barang: citraan, status, atau kemampuan seseorang yang dipertinggi, kesan atas kekayaan atau selera yang halus. Hal ini terkait dengan gaya hidup yang menurut Toffler dalam Walker (2010) merupakan wahana yang dengannya individu mensinyalkan identifikasi mereka dengan subkultur khusus. Setiap gaya hidup dikonstruksi dari mosaik berbagai item, oleh karenanya gaya hidup merupakan semacam 'super-produk' yang menawarkan cara mengorganisasikan produk dan ide.

\section{METODE PENELITIAN}

Lokasi penelitian di toko-toko rokok elektrik yang ada di Kota Lhokseumawe, diantaranya Octopus yang beralamat di Jalan Malikussaleh, Lancang Garam Banda Sakti; Vape Rock N Roll yang beralamat di Jalan Darussalam, Hagu Selatan Banda Sakti; dan Vapor Lhokseumawe yang beralamat di Jalan Cut Mutia, Pusong Baru, Banda Sakti. Pendekatan yang digunakan dalam penelitian ini adalah pendekatan kualitatif dengan studi kajian budaya dan konsumerisme. Data yang diperoleh dalam penelitian ini adalah data kualitatif yang berwujud pertanyaan-pertanyaan mengenai isi, sifat, ciri, dan keadaan dari suatu gejala (Ahimsa-Putra, 2009). Bukti penelitian berupa pembicaraan yang sebenarnya, isyarat, dan tindakan sosial lainnya sebagai bahan mentah untuk analisis kualitatif (Mulyana, 2008). Informan yang menjadi sumber data terkait dengan tema penelitian ini antara lain informan yang sudah ditentukan dapat memberikan informasi yang koheren dan mendalam, diantaranya konsumen rokok elektrik, pemilik toko vape, dan akademisi. Sumber data terdiri atas kata-kata dan tindakan, sumber tertulis, dan foto (Ruslan, 2004; Moleong, 2014). Untuk mendapatkan data dan informasi yang diperlukan, peneliti menggunakan empat macam teknik pengumpulan data yaitu observasi, wawancara, studi dokumen, dan studi literatur. Analisis data dilakukan sejak awal dan sepanjang proses penelitian berlangsung.

95 | Jurnal Ilmu Sosial dan Ilmu Politik Malikussaleh (JSPM) Volume 2 Nomor 1 Tahun 2021 


\section{HASIL DAN PEMBAHASAN}

\section{Budaya Merokok di Kota Lhokseumawe}

Sebelum berbicara tentang rokok elektrik yang sedang naik daun, tentu kita perlu membahas tentang rokok konvensional yang digunakan sebelum vape hadir di kalangan masyarakat Kota Lhokseumawe. Dalam masyarakat Aceh pada umumnya, sama seperti wilayah Indonesia lainnya, rokok sudah menjadi suatu hal yang lumrah. Bahkan sebuah penelitian menunjukkan jika sebesar 51,1 persen rakyat Indonesia adalah perokok aktif dan masuk dalam jajaran tertinggi se ASEAN (Wikipedia, diakses pada 20 Mei 2019). Jadi, bukan suatu hal yang baru jika kita melihat banyak orang Aceh terkhusus Kota Lhokseumawe merokok. Sebagian besar dari perokok di Aceh atau dapat kita lihat hampir seluruhnya merupakan laki-laki. Tidak ada atau jarang ditemui adanya kaum perempuan yang merokok. Hal ini bahkan terlihat dalam pemaparan informan berikut ini:

"Ya memang di Aceh nyoe hana yang nama jih ureung inong i pip rukok. Nyan hamper hana ta meurumpok yang lagee nyan hino. Laen cerita meuseu ta jak bak medan, nyan that lheu awak inong meurukok. Nyan kah biasa bagi ureung nyan, man hino hana lagee nyan. Aceh nyoe kan na aturan jih, na qanun berlandaskan agam yang mengatur. Ureung inong neusok lueu mantoeng hanjeut pu lom yak pep rukok. Nyan keuh, sagai cuma ureung agam yang piep rukok, meunyoe ureung inong yang pie meuhi gura bak takaloen, jareung na ureung ino man jeut ta peugah sit hana. Meunan lah...." (Ramlan, Desa Alue Awe, 18/05/2019).

Selain itu, secara budaya, merokok bagi masyarakat Kota Lhokseumawe yang notabene perokok adalah suatu bagian dari kehidupan sehari-hari mereka. Dalam sehari, beberapa aktivitas yang dilakukan tidak terlepas dari penggunaan rokok misalnya setelah makan. Para perokok cenderung membakar rokok dan menghisapnya, baik sehabis sarapan, makan siang, maupun makan malam. Tidak hanya itu, para perokok juga kebanyakan terbiasa merokok pada saat buang air besar atau mengerjakan suatu pekerjaan yang menyita konsentrasi. Lebih jauh lagi, di Kota Lhokseumawe yang menjadi bagian dari Aceh yang terkenal akan negeri seribu warung kopinya. Budaya "ngopi" sudah menjadi suatu hal yang lumrah bagi masyarakat di Lhokseumawe dan dalam hal ini, merokok juga menjadi bagian dari adat budaya tersebut. Merokok sambil "ngopi" dan "nongkrong" bersama kenalan atau kolega adalah hal yang begitu sering dilakukan perokok Kota Lhokseumawe. Penjelasan tentang ini dapat dilihat pada kutipan wawancara berikut ini:

“... Biasa jih memang mandum tempat nyan adat meurukok jih sama. Koen sama chit ngoen cara droe keuh pip rukok, paleng pah watee lheuh tapajoh bu, nak mangat babah teuh. Lheuh nyan kadang-kadang sita ta boeh hadah tapiep rukok. Watee ta duk-duk di warong kupie sira ta jeb kupie, keu mangat kupie chit. Kadang-kadang watee tapubuet sipupu,

96 | Jurnal Ilmu Sosial dan Ilmu Politik Malikussaleh (JSPM) Volume 2 Nomor 1 Tahun 2021 
meusibak koen beuna keu asoe jaroe. Nyan jih, ta pip lah rukok. Bah mangat." (Ramlan, Desa Alue Awe, 18/05/2019).

Penjelasan di atas juga sudah cukup menunjukkan bahwa rokok adalah bagian dari keseharian masyarakat di Kota Lhokseumawe. Banyak hal dilakukan para perokok sembari mengkonsumsi rokok mereka. Bahkan kebiasaan tersebut tidak lagi dibatasi dan cenderung dilakukan di tempat-tempat yang harusnya menjadi tempat bebas asap rokok. Seperti fasilitasfasilitas umum yang notabene harus menjamin keselamatan kelompok masyarakat bukan perokok dari polusi asap rokok. Adapun aturan tentang hal ini juga telah tercanang di dalam Qanun Nomor 5 Tahun 2016 tentang Kawasan Tanpa Rokok (KTR) dengan memberikan sanksi Tindak Pidana Ringan (Tipiring) kepada perokok di area publik (Serambinews.com, 24 Mei 2018).

Aturan yang tertuang dalam Qanun Aceh di atas sudah cukup menjelaskan seberapa pemerintah ingin mengurangi kebiasaan merokok di tempat-tempat umum. Akan tetapi, merubah sesuatu yang telah membudaya tentu bukan perkara mudah. Masyarakat Aceh yang sebagian besar telah terbiasa dengan rokok sebagai bagian dari kehidupan sehari-hari, tentu cukup sulit untuk membiasakan diri dengan aturan yang baru ditetapkan tiga tahun lalu tersebut. Hadirnya vape sedikit banyak memberi pengaruh dalam hal mengurangi pengguna rokok konvensional. Walau kembali lagi, belum ada data akurat yang menunjukkan bahwa rokok elektrik benar-benar secara signifikan mampu menekan jumlah perokok biasa di Kota Lhokseumawe.

\section{Tren Rokok Elektrik (Vape) di Kota Lhokseumawe dan Faktor Penyebab}

Kebiasaan merokok di Indonesia merupakan suatu pemandangan yang sudah tidak asing lagi. Hampir di setiap tempat, bahkan di ruang publik pun sering ditemui para perokok. Padahal, rokok telah menjadi salah satu ancaman mematikan di dunia. Termasuk Indonesia yang tak terlepas dari ancaman tersebut dan telah dinyatakan sebagai negara dengan pengguna tembakau terbesar ketiga di dunia, serta menduduki peringkat pertama di Asia Tenggara. Jumlah perokok di Indonesia mencapai 62.800.000 jiwa, atau pada tahun 2016 setara dengan 36,3\% dari total penduduk Indonesia merupakan perokok aktif. Selain itu, pada sumber yang sama menjelaskan jika berdasar pada penelitian yang pernah dilakukan, diketahui setiap hari ada 616.881.205 batang di Indonesia atau 225.161.640.007 batang rokok yang dibakar setiap tahunnya (Istiqamah et al., 2016).

Data di atas menunjukkan jika kebiasaan merokok konvensional masih begitu melekat pada sebagian besar masyarakat Indonesia. Padahal, sudah banyak riset dan contoh kasus yang menyebutkan efek negatif dari mengonsumi rokok tersebut. Sehingga, seiring berkembangnya zaman dan teknologi, ditemui inovasi baru yang dipercaya dapat menjadi jawaban atas 
permasalahan bahaya rokok konvensional tersebut, yaitu vape atau rokok elektrik. Vape pertama kali dikenalkan pada tahun 2003 oleh sebuah perusahaan yang ada di Cina. Sejak dikenalkan dan dikeluarkan di tahun tersebut, rokok elektrik dengan cepat menyebar ke seluruh dunia dan mulai memiliki nama dagang seperti NJOY, Epuffer, blu cig, green smoke, smoking everywhere, dan lain-lain (Damayanti, 2016).

Kemunculan rokok jenis ini sangat disambut baik mulanya karena dipercaya sangat efektif dalam membantu para pecandu rokok konvensional untuk berhenti dari kebiasaan merokok mereka. Sehingga proses rokok elektrik marak dan menjadi sebuah tren di kalangan masyarakat sangat cepat. Di Indonesia sendiri, vape disepakati masuk untuk pertama kalinya pada tahun 2010. Walau perkembangan vape pada mula kedatangannya tidak langsung terkenal, karena pada saat itu masyarakat Indonesia belum tahu persis soal vape, namun sekitar tahun 2013-2014 perkembangannya mulai meningkat pesat. Banyak masyarakat di Indonesia pada saat itu beramairamai membeli dan mulai menggunakan rokok elektrik untuk mengganti kebiasaan merokok konvensional (Sakti dalam Gunawan, 2018), termasuk pula pada kalangan perokok di Kota Lhokseumawe.

Menurut Electronic Cigarette Association secara umum sebuah rokok elektronik terdiri dari 3 bagian yaitu: battery (bagian yang berisi baterai), atomizer (bagian yang memanaskan dan menguapkan larutan nikotin) dan catridge (berisi larutan nikotin). Berikut ini adalah contoh visualisasi rokok elektrik atau vape dan liquid-nya yang berhasil peneliti peroleh dari pengguna vape di Lhokseumawe:

Gambar 1. Contoh Vape yang Dimiliki Pengguna di Kota Lhokseumawe

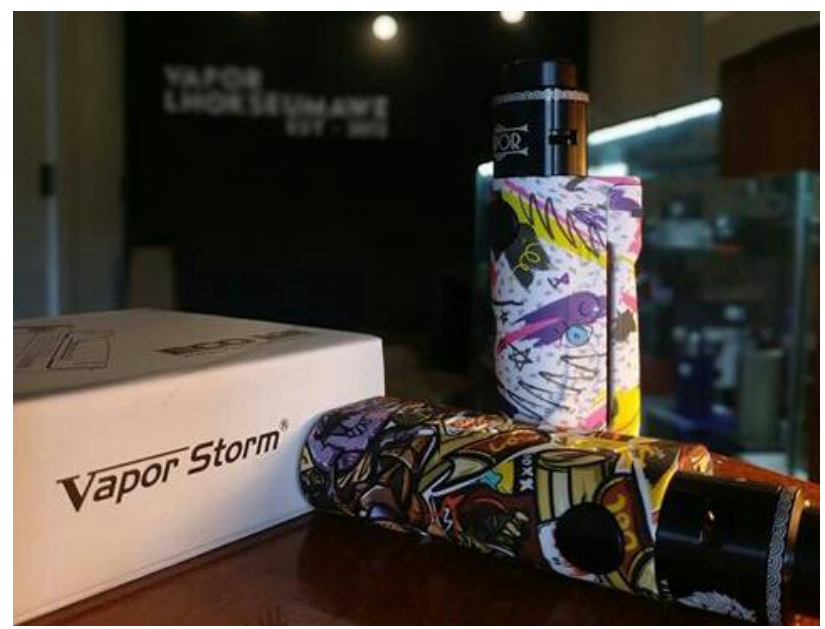

Sumber: dokumentasi penelitian, 2019

98 Jurnal Ilmu Sosial dan Ilmu Politik Malikussaleh (JSPM) Volume 2 Nomor 1 Tahun 2021 
Pada gambar di atas terlihat bagaimana tampilan fisik dan body dari vape dapat didekorasi sesuai selera penggunanya. Tidak melulu menggunakan warna-warna yang biasa dan monoton, namun bagian luar atau body vape bisa diberi atau ditempel skin atau sticker box dengan berbagai warna dan gambar sesuai keinginan pemilik. Untuk stiker vape dapat diperoleh melalui toko-toko khusus penjual vape maupun secara online. Untuk kisaran harga beragam, tergantung jenis, model dan ukuran stiker yang dipilih. Selain itu, sebuah vape tentu tidak akan berfungsi jika tidak diisi dengan liquid atau cairan vape-nya. Liquid tersebut memiliki varian rasa yang memberi sensasi lebih dibandingkan rokok, sehingga hal ini pula yang membuat orang-orang mulai banyak beralih menggunakan vape dibanding dengan rokok konvensional. Berikut ini adalah visualisasi dari liquid yang digunakan beberapa vapor Lhokseumawe.

\section{Gambar 2. Contoh Vape dan Liquid yang Dimiliki Pengguna Vape di Kota Lhokseumawe dan Varian lainnya}

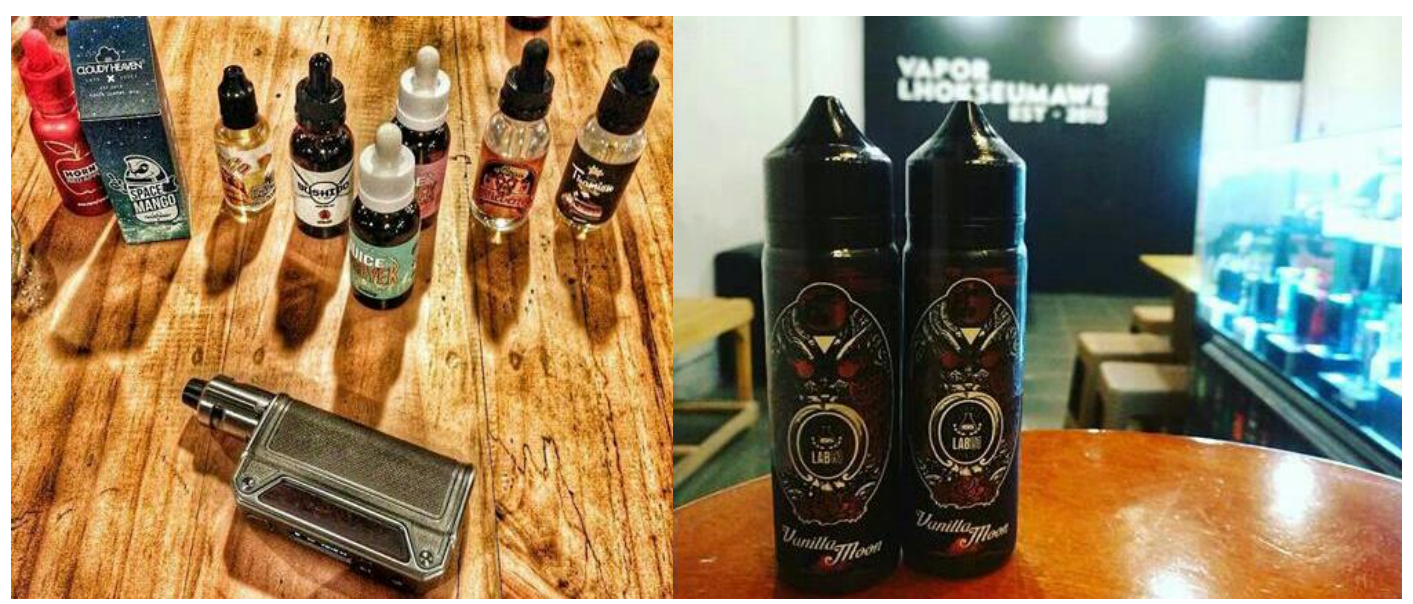

Sumber: dokumentasi penelitian, 2019

Selain soal varian rasa, liquid juga mengandung nikotin dan perlu diketahui ada pula liquid yang tidak memiliki kandungan nikotin. Namun di luar itu semua, yang menjadi daya tarik lain dari vape adalah liquid-nya yang memiliki beragam rasa, terdapat rasa creamy, fruity atau buahbuahan, rasa rokok biasa dan lain-lain. Untuk harga dari tiap liquid ini juga bermacam-macam, tergantung merek atau brand-nya. Akan tetapi harga liquid-liquid tersebut berkisar pada Rp. 50.000,- hingga Rp.200.000,- lebih. Terasa berat memang pengeluaran sebanyak itu jika dibandingkan dengan rokok konvensional yang tak sampai beratus ribu. Hanya saja, jumlah tersebut merupakan investasi. Vape menuntut penggunanya untuk mengeluarkan uang lebih di muka. Artinya, pengguna vape tidak perlu mengeluarkan uang berkali-kali sebagaimana membeli 
rokok biasa. Liquid vape tersebut bisa digunakan untuk beberapa kali pakai selama dua minggu lebih, dan jika dihitung secara keseluruhan, perbandingan antara pengeluaran untuk rokok konvensional dan rokok elektrik, diketahui rokok konvensional masih jauh lebih boros (wawancara, Hendra, 22/11/2018).

Gambar 3. Situasi Toko Vapor Lhokseumawe

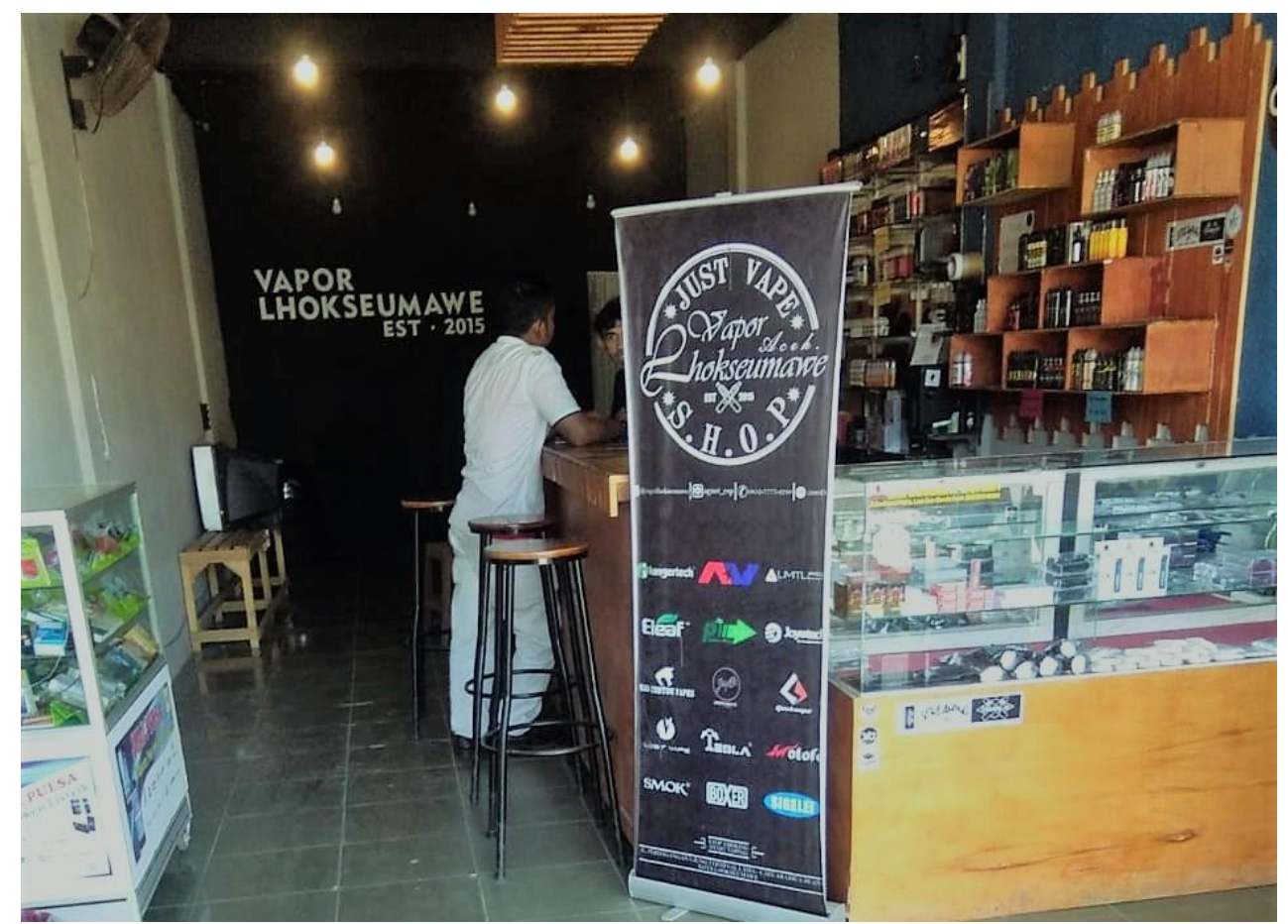

Sumber: dokumentasi penelitian, 2019

Di Lhokseumawe sendiri, vape hadir pertama kali pada tahun 2015. Hingga saat ini jumlah toko atau gerai yang menjual rokok elektrik atau vape beserta dengan aksesorisnya yang memiliki izin di Lhokseumawe diketahui berjumlah tiga toko, yaitu Toko Octopus, Toko Vapor Lhokseumawe, dan Toko Vape Rock n Roll. Adapun masuknya vape di Kota Lhokseumawe dikarenakan mengikuti perkembangan dan eksistensinya di Indonesia sendiri yang mulai marak bermunculan pada tahun 2012. Cukup terlambat memang, bahkan masuknya rokok jenis ini di Indonesia sendiri juga terbilang lama jika dibandingkan dengan negara-negara lainnya atau semenjak lahirnya rokok tersebut di China pada tahun 2003. Saat itu, vape muncul sebagai sebuah inovasi dan alternatif guna menanggulangi candu akan rokok konvensional. Ini sesuai dengan kutipan wawancara berikut ini:

"Memang vape ini kan maraknya di Indonesia ini sekitaran tahun 2012. Waktu itu lagi rame-ramenya. Banyak yang pake. Sampai ke mari di Lhokseumawe ini juga udah mulai 
marak rokok itu. Satu-satu pertama yang bawa dari luar kan ya, terus dikenalin kemari. Dibilang rokok ini lebih rendah efek sampingnya dibanding rokok biasa. Yaudah lah mulai rame, makanya kami pun saat itu melihat ada peluang di bidang ini. Wah! Kenapa gak dicoba aja buka usaha di bidang ini, kebetulan saya ada sedikit modal saat itu. Yaudah, buka lah kedai ini kecil-kecilan. Untuk sekedar jual alat sama isi ulang kan. Lama-lama pun berkembang, pembeli makin banyak terus sering juga anak-anak kumpul di sini. Yaudah, kami buat aja komunitas sekalian. Buat nongkrong, ngobrol-ngobrol soal vaping lah." (Saiful, Toko Vapor Lhokseumawe, 22/11/2018).

Merujuk pada kesempatan wawancara yang sama, peneliti juga mendapati informasi terkait bagaimana vape yang merupakan budaya dari luar masuk karena banyaknya pelancong-pelancong yang tengah liburan di luar negeri mengetahui informasi soal vape lantas membelinya dan membawanya pulang ke Indonesia, dalam hal ini Lhokseumawe, Aceh. Saat itu rokok elektrik belum terlalu booming namun lama-kelamaan seiring perkembangan zaman dan maraknya beragam informasi terkait rokok elektrik, maka mulailah trend ngevape marak. Hanya pada tahun 2014, trend ini sempat meredup dikarenakan adanya isu dan rumor yang mengatakan jika vape nyatanya memiliki efek samping yang lebih buruk dari rokok konvensional. Namun kini, isu tersebut tak terbukti dan kian menghilang sehingga semakin kemari pengguna vape semakin bertambah.

Semakin banyaknya pengguna vape di Lhokseumawe, juga membuktikan eksistensi vape di kalangan perokok Lhokseumawe. Telah bermunculan beberapa komunitas vapor yang dibentuk tidak sekedar sebagai wadah berkumpulnya para perokok elektrik di Kota Lhokseumawe. Namun juga menjadi tempat bagi mereka untuk berbincang, berdiskusi seputar mod vape, liquid (isi ulang rokok elektrik), hingga kepada trik-trik yang bisa dimainkan oleh para anggota komunitas tersebut ketika mereka sedang ngevape dan menikmati sensasi vaping. Penjelasan ini peneliti peroleh dari pemaparan yang disampaikan salah satu informan yang merupakan salah seorang anggota komunitas vaporizer Lhokseumawe, berikut ini:

“... meunyoe tapike man mangat lom rukok vape nyoe. Jih hana that brat lage rukok biasa. Maka jih lon galak ku pet rukok nyoe, anteuk sekalian duek-duek hino ngeon awak nyan, ta meurukok... ngevape. Di komunitas nyoe sit kamoe lheu peugah haba tentang liquid jih, tentang pue pue mantoeng yang jeut ta peugoet u trik jih. Pue meunoe, pue meunoe...yah galak jih kiban lah." (Acin, Toko Vape Rock n Roll, 25/12/2018).

Pada kesempatan wawancara yang sama, informan juga menceritakan tentang bagaimana pengalamannya ketika mencoba vape untuk pertama kalinya. Sebagai perokok akut sebelumnya, informan mengatakan jika ia bisa menghabiskan sebungkus rokok konvensional bahkan lebih dalam sehari. Selain itu, ia sering mengalami sesak di pagi hari dan terkadang keluar lendir ketika dulu masih merokok biasa. Namun setelah ia dikenalkan dengan vape oleh salah seorang 
kenalannya dari luar kota, informan langsung mencoba karena tertarik dengan kabar soal efektivitas vape dalam mengurangi ketergantungan rokok, dan ditambah lagi saat itu ramai dibincangkan jika vape tidak seberbahaya rokok konvensional. Maka, setelah informan menjadi seorang vapor, ia menjelaskan jika banyak perubahan yang cukup dirasakan seperti rasa sesak yang sudah jarang dirasakan, lendir yang tidak lagi keluar dari mulutnya, serta dana yang dikeluarkan tidak perlu sebanyak memakai rokok konvensional. Walau perlu diketahui jika untuk beralih dari rokok biasa ke rokok elektrik memerlukan dana awal yang terbilang besar, karena diperlukan untuk pembelian alat-alat vaping. Namun, pengeluaran di awal tersebut tidak akan berlanjut seterusnya. Pengguna hanya perlu membeli liquid sebagai cairan isi ulang yang dikonsumsi dalam jangka waktu dua minggu sekali atau lebih (tergantung pemakaian). Tidak perlu membeli terus-menerus seperti rokok biasa. Selain itu, meski memiliki perbedaan dalam hal fisik dan penggunaan dengan rokok konvensional, namun vape memiliki sensasi yang sama dengan saat merokok menggunakan rokok biasa. Hanya saja, vape memiliki varian rasa yang lebih beraneka ragam jika dibandingkan dengan rokok biasa. Itulah mengapa, banyak orang meminati rokok jenis baru ini di Kota Lhokseumawe.

Maraknya sebuah budaya yang kemudian menjadi trend pada suatu masyarakat tentu dipengaruhi oleh beberapa faktor yang melatarbelakanginya. Dalam hal ini, peneliti memperoleh data-data terkait bagaimana rokok elektrik atau vape dapat menjadi suatu trend di Kota Lhokseumawe berdasar beberapa hasil wawancara dan sumber referensi maupun literatur sebagai penguat gagasan. Adapun terdapat beberapa yang dikategorikan sebagai faktor dari menjadi trendnya rokok elektrik di kalangan masyarakat Kota Lhokseumawe (terkhusus kaum perokok), yaitu sebagai berikut:

Pertama, tentu gaya hidup menjadi faktor utama yang memengaruhi. Perkembangan gaya hidup yang bermula dari Indonesia sebagai sebuah negara, mau tak mau juga membuat trend vape di kalangan nasional juga turut terjadi pada masyarakat di Kota Lhokseumawe. Mengikuti kebiasaan merokok dengan rokok elektrik dirasa turut menaikkan nilai prestise penggunanya dan juga mengangkat kelas sosialnya di masyarakat. Begitu pula pada kaum perokok di Kota Lhokseumawe, terutama bagi mereka kalangan anak muda.

Faktor kedua yang menjadikan vape sebagai sebuah trend di Kota Lhokseumawe adalah karena adanya anggapan bahwa vape dapat digunakan sebagai alternatif dalam menghilangkan candu akan rokok. Rumor tentang kandungan dari vape yang jauh lebih baik dibanding rokok konvensional serta pengaruhnya yang dapat membuat pecandu rokok menjadi terlepas dari rokok konvensional, tentu menggiring opini dan keinginan perokok untuk berduyun-duyun menggunakan 
rokok jenis ini. Meski secara gamblang dan konkrit belum ada penelitian yang membuktikan jika vape lebih baik dari rokok biasa.

Faktor ketiga adalah keunikannya dalam hal menghasilkan uap (menyerupai asap tebal) yang dapat dibentuk sedemikian rupa. Maka, selain digunakan sebagai alternatif bagi pecandu rokok, vape juga sudah mulai digunakan sebagai wadah mengekpresikan kreativitas diri. Sudah banyak event-event yang mengadakan perlombaan membentuk atau mengkreasikan uap vape. Baik perlombaan skala kecil yang diadakan oleh komunitas-komunitas berbasis kota maupun berskala besar yang melibatkan banyak komunitas dan para vapor dari berbagai kalangan. Di Lhokseumawe sendiri, diketahui jika perlombaan serupa memang belum pernah diadakan. Namun, tidak jarang beberapa anggota dari kelompoknya mengikuti secara pribadi event-event serupa yang diadakan di luar kota. Namun, di luar itu semua, seni membentuk uap vape tetap menjadi suatu nilai lebih yang dimiliki rokok elektrik. Hal ini senada dengan penjelasan informan berikut ini:

"Memang kan lebih menarik vape ini karena dia punya banyak kelebihan lah kalo kita bandingin sama rokok biasa. Rokok kan ya cuma beli, trus dibakar udah abis gitu aja. Mana bau juga kalo rokok biasa kan tinggal. Tapi kalo vape ini kita gak bau abis merokoknya, kita pun bisa mainin asap atau uapnya itu. Menarik lah, bisa jadi hobi juga kalo saya. Sering juga buka-buka youtube untuk ngecek atau nonton video tutorial bentuk uap rokok ini. Rupanya memang udah ada dia seninya itu sekarang, jadi ya saya sering lah belajar-belajar sendiri dari hape atau gak sharing-sharing sama orang ini di sini." (Fikri, Kota Lhokseumawe, 25/12/2018).

Selain hal-hal di atas, faktor lainnya yang juga memengaruhi vape menjadi sebuah trend di Kota Lhokseumawe adalah karena varian rasa yang dimilikinya. Terdapat beragam rasa yang memberi sensasi berbeda dan baru bagi perokok yang menggunakan rokok jenis ini. Tentu, rasarasa tersebut tidak dimiliki oleh rokok biasa dan memberikan sensasi aroma yang jauh lebih harum dan sedap jika dibandingkan dengan bau rokok biasa. Selain itu, dalam hal harga jika diakumulasikan pengeluaran untuk rokok konvensional dalam sebulan, maka jika dibandingkan dengan rokok elektrik atau vape maka akan jauh lebih hemat pengeluaran memakai vape. Hanya saja, vape membutuhkan pengeluaran dana yang cukup besar di awalnya, berbeda dengan rokok yang hanya butuh dana jauh lebih sedikit jika dibanding dengan pembelian vape untuk sekali beli per bungkusnya.

\section{Pengaruh, Gaya Hidup, dan Budaya Pop Pengguna Rokok Elektrik di Kota Lhokseumawe}

Seiring dengan kemajuan zaman dan teknologi, perkembangan gaya hidup dewasa ini juga terlihat cukup pesat. Tidak hanya secara global, namun juga terjadi pada masyarakat Indonesia di beberapa bagian terkecil wilayahnya. Sering ditemui masyarakat yang mengikuti perkembangan 
gaya hidup seiring dengan munculnya tren-tren maupun pusat-pusat perbelanjaan, industri mode, kawasan hunian mewah, apartemen, dan lain sebagainya. Banyaknya masyarakat Indonesia yang tertarik dengan perkembangan gaya hidup membuat industri yang berkecimpung di bidang gaya hidup bersaing untuk menciptakan inovasi-inovasi terkini dan muktahir guna menarik minat masyarakat. Pada gilirannya, maraknya perkembangan gaya hidup di Indonesia membuat masyarakat yang hidup dalam lingkup perkotaan memiliki kepribadian konsumtif.

Masyarakat yang hidup di lingkup perkotaan tentu memiliki gaya hidup yang berbeda dengan mereka yang tinggal di wilayah pedesaan. Masyarakat perkotaan cenderung modern dan menggunakan gagasan tentang gaya hidup untuk menggambarkan tindakannya sendiri maupun orang lain. Bisa dikatakan jika masyarakat masa kini terkhusus perkotaan, cenderung mementingkan membeli atau menggunakan sebuah produk gaya hidup untuk menunjukkan bahwa dirinya adalah seseorang yang mengikuti perkembangan zaman dan terkadang tidak lagi mementingkan kegunaan dari produk itu sendiri. Sama halnya dengan vape yang belum memiliki legalitas penggunaannya di Indonesia dan juga belum bisa dibuktikan sebagai inovasi yang jauh lebih sehat dibanding rokok konvensional.

Hal ini juga terjadi pada vaper (pengguna rokok elektrik) di Kota Lhokseumawe. Sebagian besar dari mereka bukan lagi menggunakan rokok elektrik atau vape sebagai cara untuk menghentikan kebiasaan merokok konvensional. Namun, mereka menjadikan vape sebagai suatu gaya hidup yang perlahan berubah menjadi suatu pola kegemaran (hobi). Hal ini turut menjadi studi dalam konsepsi konsumtif. Dimana budaya penggemar (fan culture) dan dalam pelbagai studi tentang belanja merupakan suatu bentuk budaya pop (Storey, 2010). Vape digunakan sebagai suatu sarana pemuas hobi/kegemaran bagi sebagian orang. Beberapa diantara mereka tetap menggunakan rokok konvensional di kehidupan sehari-hari dan vape hanya digunakan ketika mereka merasa ingin memakainya atau pada saat ada event-event di komunitas vapor di Lhokseumawe. Penjelasan tentang ini terlihat pada kutipan wawancara berikut ini:

"Kalau sehari-hari saya pribadi memang ngerokok juga. Ya tetep susahlah lepas dari rokok model biasa itu. Apalagi ngevape ini kan agak ribet ya urusannya. Kita mesti coiling, ganti kapas, ngecasnya lagi. Tapi kalo rokok biasa kan kita tinggal ambil rokok terus bakar, selesai. Habis itu pun, kalau mau beli liquid-nya harus sedia duit lebih daripada beli rokok biasa. Liquid itu harganya berkisar limpol sampai lima ratus ribuan. Tapi pemakaiannya lumayan lah gak untuk sekali pakai. Cuma ya itu, kita kalau ngevape ini memang biaya awalnya itu besar. Tapi kalau dihitung-hitung lebih murahan ngevape dibanding ngerokok biasa." (Adi, Kota Lhokseumawe, 15/11/2018).

Pada akhirnya, di kesempatan wawancara yang sama, informan juga menjelaskan jika kehadiran vape di Kota Lhokseumawe bukan lagi difungsikan sebagai alat memenuhi hasrat 
merokok bagi pecandu rokok dan sebagai inovasi dalam menyembuhkan candu rokok itu sendiri (seperti tujuan awal terciptanya vape). Namun, lebih jauh lagi, vape telah berubah menjadi sebuah gaya hidup dan perlahan membudaya. Suatu kebudayaan dapat terbentuk karena suatu kebiasaan yang dilakukan secara terus-menerus dan berulang-ulang. Suatu kebiasaan dapat terbentuk karena adanya sistem sosial yaitu berupa aktivitas-aktivitas manusia yang saling berinteraksi, berhubungan, serta bergaul dengan satu sama lain (Koentjaraningrat, 1986). Situasi di mana vape telah menjadi suatu gaya hidup baru di beberapa kalangan perokok di Kota Lhokseumawe juga tergambar dalam kutipan wawancara berikut ini:

"Memang ya semenjak vape ini masuk ke Lhok ini, atau sejak mulai booming-boomingnya dulu lah. Itu memang uda banyak yang mulai penasaran dengan rokok ini. Pertama dulu itu memang kalangan-kalangan atas lah yang langsung beli gitu kan, mereka mungkin emang udah pada tau kegunaannya karena mungkin banyak teman-temannya yang dari luar kota udah pada pake. Cuma lama-lama setelah rame yang tahu kalo ini ada manfaatnya, bisa bikin hilang candu sama rokok, jadi udah mulai rame juga yang beli. Karena dia emang kalo untuk pemula beli semua-semua alat dan keperluan vape ini kita bilang cukup mahal lah. Beda sama rokok biasa itu kan beli per bungkus-bungkus paling berapa lah gak sampe beratus ribu habisnya. Cuma kan memang tidak semua perokok di Lhok ini otomatis pindah ke vape, banyak juga yang enggak. Nah, kadang mungkin adalah terasa gitu bagi pengguna vape ini rasa-rasa oh, aku keren nih pake vape, adalah rasa bangga gitu kalo misal duduk di kafe atau kede kopi, keluarin rokok ini kan keren dibanding orang lain yang ngerokok biasa." (Hendra, Toko Octopus Lhokseumawe, 15/11/2018).

Kebiasaan penggunaan rokok elektrik (vape) yang telah menjadi suatu gaya hidup baru memang berujung pada sikap konsumerisme. Bourdieu (1984), memaparkan pendapatnya tentang bagaimana kita menggunakan konsumsi untuk tujuan pembedaan sosial sebagai perluasan kerangka gagasan Veblen tentang pembedaan diri (Bakti et al., 2020). Bourdieu berpendapat bahwa gaya hidup adalah suatu arena penting bagi pertarungan di antara berbagai kelompok dan kelas sosial. Bagi Bourdieu, konsumsi terhadap suatu budaya itu cenderung sadar dan mengisi suatu fungsi sosial berupa melegemitasi perbedaan-perbedaan sosial.

Pendapat Bourdieu tersebut cukup sesuai dengan fenomena rokok elektrik atau vape di Kota Lhokseumawe. Di mana kehadiran vape sebagai suatu komoditi gaya hidup baru di tengah-tengah masyarakat dapat menjadi suatu budaya baru yang digandrungi dan menciptakan sikap konsumtif. Namun pada akhirnya, kebiasaan konsumtif tersebut menggiring penggunanya membentuk suatu kelompok-kelompok atau kelas-kelas sosial yang dalam hal ini terwujud lewat lahirnya komunitas vape di Kota Lhokseumawe. Tanpa disadari, mereka telah membentuk suatu pembedaan kelas antara diri mereka yang menggunakan rokok elektrik dengan orang lain yang merokok dengan rokok konvensional. Tentu, hal tersebut membentuk kelas sosial diantara kaum perokok di Kota 
Lhokseumawe karena tak bisa dipungkiri, nilai prestise, elegansi, dan classy yang dimiliki rokok elektrik (vape) menjadi salah satu faktor yang menyebabkan terbentuknya kelas-kelas tersebut.

Gambar 4. Konsumen Vape di Kota Lhokseumawe

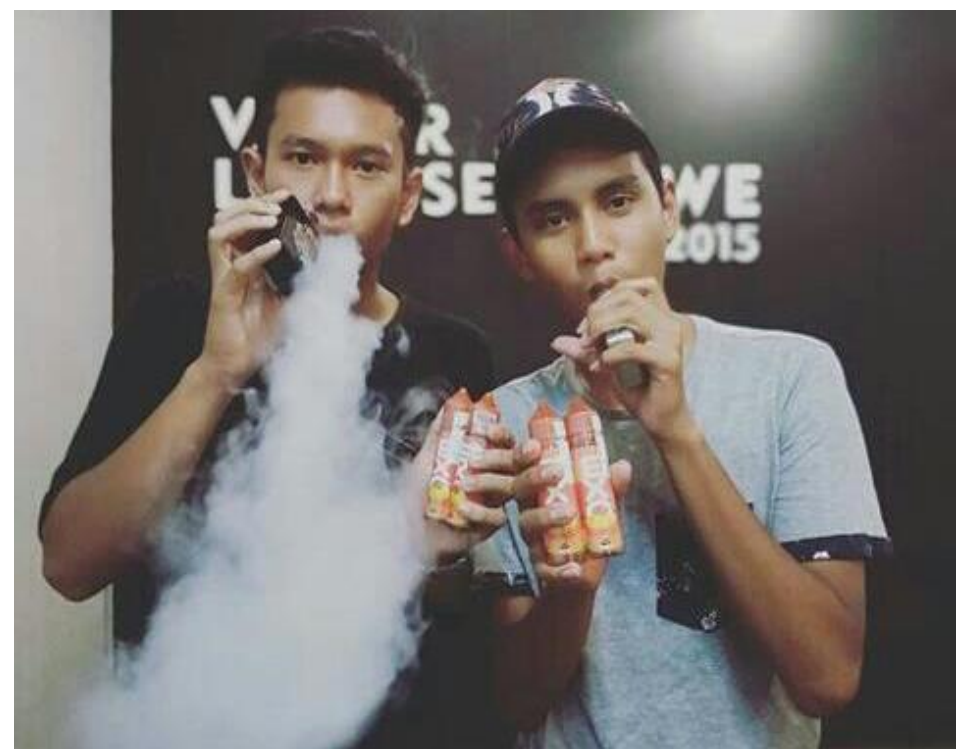

Sumber: dokumentasi penelitian, 2019.

\section{KESIMPULAN}

Rokok elektrik atau dikenal sebagai vape pertama kali masuk ke Kota Lhokseumawe pada tahun 2015 silam. Muncul sebagai sebuah inovasi dalam mengurangi candu akan rokok konvensional. Vape pun mulai digandrungi para perokok di Lhokseumawe sehingga mulai terdapat beberapa toko yang menjual keperluan dan alat vape. Berdasarkan data yang diperoleh, diketahui jika ternyata faktor-faktor yang mempengaruhi vape menjadi sebuah tren di Kota Lhokseumawe antara lain: 1) pengaruh gaya hidup; 2) anggapan atau informasi tentang manfaat vape yang dapat menyembuhkan candu terhadap rokok biasa (di mana vape dianggap tidak memiliki efek samping seberat penggunaan terhadap rokok konvensional); 3) keunikan vape dalam menghasilkan uap atau asap yang banyak sehingga dapat dikreasikan dan dijadikan sebuah hobi baru; 4) alasan vape memiliki cita rasa yang unik; dan 5) liquid-liquid beragam rasa yang digunakan menghasilkan bau atau aroma yang harum pula.

Adapun pengaruh vape terhadap perilaku perokok di Kota Lhokseumawe paling tampak tentu dalam hal gaya hidup. Perokok yang telah beralih dari rokok konvensional ke vape, kenyataannya cenderung merasa memiliki nilai prestise yang lebih tinggi dibanding perokok biasa. Selain itu, ada pula sebagian dari vapor tersebut yang tidak sepenuhnya menjadi perokok elektrik. 
Mereka masih menggunakan rokok biasa pada momen tertentu dan menjadikan vape sebagai hobi semata. Jika sudah demikian, maka hasrat untuk memuaskan diri mereka akan hobi baru mereka ini akan mengantarkan para vapor menjadi pribadi yang konsumtif. Mereka akan membeli beberapa keperluan dan hal mendukung lainnya terkait vape. Mereka akan berkumpul dengan sesama vapor di Kota Lhokseumawe untuk sekedar "ngerokok" bersama atau berbagi info dan ilmu seputar vape. Pada akhirnya, hal ini berujung pada terbentuknya kotak-kotak, kelas-kelas, atau kelompok di antara para perokok di Kota Lhokseumawe, di mana terdapat kelompok perokok biasa dan kelompok vapor yang dipandang memiliki nilai prestis lebih.

\section{DAFTAR PUSTAKA}

Ahimsa-Putra, H. S. (2009). Paradigma Ilmu Sosial-Budaya. Kuliah Umum "Paradigma Penelitian Ilmu-Ilmu Humaniora." Makalah. Program Studi Linguistik Sekolah Pascasarjana Universitas Pendidikan Indonesia.

Alfitri, A. (2007). Budaya Konsumerisme Masyarakat Perkotaan. Empirika FISIP Unsri, 11(1), 110.

Atmojo, W. S. (2017). Pengambilan Keputusan Perokok Tembakau yang Beralih ke Rokok Elektrik. Skripsi. Universitas Negeri Surakarta.

Badan Pengawasan Obat dan Makanan (2015). Bahaya Rokok Elektronik: Racun Berbalut Teknologi. Majalah Info BPOM 16(5).

Bakti, I. S., Nirzalin, N., \& Alwi, A. (2019). Konsumerisme dalam Perspektif Jean Baudrillard. Jurnal Sosiologi USK (Media Pemikiran \& Aplikasi), 13(2), 147-166.

Bakti, I., Anismar, A., \& Amin, K. (2020). Pamer Kemewahan: Kajian Teori Konsumsi Thorstein Veblen. Jurnal Sosiologi USK (Media Pemikiran \& Aplikasi), 14(1), 81-98.

Bourdieu, P. (1984). Distinction: A Social Critique of the Judgement of Taste. Harvard University Press.

Damayanti, A. (2016). Penggunaan Rokok Elektronik di Komunitas Personal Vaporizer Surabaya. Jurnal Berkala Epidemiologi, 4(2), 250-261.

Fikriyah, S., \& Febrijanto, Y. (2012). Faktor-Faktor yang Mempengaruhi Perilaku Merokok pada Mahasiswa Laki-Laki di Asrama Putra. Jurnal STIKES, 5(1), 99-109.

Fiske, J. (2011). Memahami Budaya Populer. Jalasutra.

Global Youth Tobacco Survey (2019). Lembar Informasi Indonesia. Diakses 26 Mei 2020. https://www.who.int/docs/default-source/searo/indonesia/indonesia-gyts-2019-factsheet(ages-13-15)-(final)-indonesian-final.pdf?sfvrsn=b99e597b_2 
Gunawan, J. (2018). Perancangan Informasi Fenomena Vape Melalui Film Dokumenter. Disertasi. Universitas Komputer Indonesia.

Istiqomah, D. R., Cahyo, K., \& Indraswari, R. (2016). Gaya Hidup Komunitas Rokok Elektrik Semarang Vaper Corner. Jurnal Kesehatan Masyarakat (Undip), 4(2), 203-212.

Keesing, R. M. (1981). Antropologi Budaya “Suatu Perspektif Kontemporer”. PT Gelora Aksara.

Koentjaraningrat (2009). Pengantar Ilmu Antropologi. Rineka Cipta.

Marisa, R. (2017). Kegilaan Para Fashionista (Studi Kajian Budaya terhadap Konsumerisme Tas Branded 'KW'di Kabupaten Aceh Tamiang). Aceh Anthropological Journal, 1(2), 64-85.

Moleong, L. J. (2005). Metodologi Penelitian Kualitatif. PT Remaja Rosdakarya.

Mulyana, D. (2008). Metodologi Penelitian Kualitatif: Paradigma Baru Ilmu Komunikasi dan Ilmu Sosial Lainnya. PT Remaja Rosdakarya.

Ruslan, R. (2004). Metode Penelitian Public Relation dan Komunikasi. PT RajaGrafindo Persada.

Serambinews.com (2018). "Merokok di Tempat Umum akan Didenda". Diakses 7 Juli 2019. https://aceh.tribunnews.com/2018/05/24/merokok-di-tempat-umum-akan-didenda

Storey, J. (2010). Cultural Studies dan Kajian Budaya Pop: Pengantar Komprehensif Teori dan Metode. Jalasutra.

Walker, J. A. (2010). Desain, Sejarah, Budaya: Sebuah Pengantar Komprehensif. Jalasutra. 